\title{
Isolation of a Relatively Pure Outer Membrane Fraction of Moraxella nonliquefaciens and a Comparison of its Characteristics with the Cytoplasmic Membrane-Containing Material
}

\author{
By E. VESLEMØY M. ANDERSEN, ${ }^{1}$ L. ODDVAR FRØHOLM ${ }^{1}$ \\ AND MORTEN M. LAANE \\ ${ }^{1}$ National Institute of Public Health, Geitmyrsveien 75, \\ Postuttak Oslo 1, Norway \\ ${ }^{2}$ Botanical Laboratory, University of Oslo, Blindern, \\ Postboks 1045, Oslo, Norway
}

(Received 15 March 1979; revised 20 June 1979)

\begin{abstract}
Cell envelope fractions of Moraxella nonliquefaciens were isolated by a slight modification of Osborn's method. Two main membrane fractions were characterized chemically and morphologically. The density of the fraction containing cytoplasmic membrane material was 1.17 to $1.18 \mathrm{~g} \mathrm{~cm}^{-3}$ compared with 1.24 to $1.27 \mathrm{~g} \mathrm{~cm}^{-3}$ for the outer membrane fraction. Lipopolysaccharide was detected almost exclusively in the outer membrane fraction and sodium dodecyl sulphate polyacrylamide gel electrophoresis of this fraction revealed one dominant protein band with an apparent molecular weight of 45000 . Cross-contamination of the fractions was estimated to be about $10 \%$, as calculated on the basis of the lipopolysaccharide fatty acid 3-hydroxydodecanoic acid and on the relative activities of D-lactate dehydrogenase and succinate dehydrogenase.
\end{abstract}

\section{INTRODUCTION}

The cell envelopes of Gram-negative bacteria consist of three morphologically distinguishable layers: the cytoplasmic membrane, the peptidoglycan layer and the external surface membrane of the cell - the outer membrane. The development of methods for the separation of these distinct layers from Gram-negative bacteria have aided the investigation of the structure and function of the bacterial cell envelope (Schnaitman, 1970; Osborn et al., 1972).

The object of the present work was to extend the method of membrane separation to Moraxella nonliquefaciens and to study the relationship between fimbriae and the isolated membrane components. The work also serves as an introduction to studies of $M$. nonliquefaciens surface antigens.

\section{METHODS}

Bacteria and media. Stock cultures of Moraxella nonliquefaciens strain 7784 SC-c (Frøholm \& Bøvre, 1978) were maintained on blood agar plates containing $3 \%(\mathrm{w} / \mathrm{v})$ tryptose blood agar (Oxoid), $0.08 \%(\mathrm{w} / \mathrm{v})$ Dextrose (Difco) and $5 \%(\mathrm{w} / \mathrm{v})$ human blood (citrated), adjusted to $\mathrm{pH} 7.6$ with $5 \mathrm{M}-\mathrm{NaOH}$. The cultures were incubated for $24 \mathrm{~h}$ at $33{ }^{\circ} \mathrm{C}$ in a humid atmosphere and then stored at $4{ }^{\circ} \mathrm{C}$. Subculture on blood agar plates was made $6 \mathrm{~h}$ before inoculation of liquid cultures in Mueller Hinton broth (Oxoid) supplemented with $0.5 \%\left(\mathrm{w} / \mathrm{v}\right.$ ) yeast extract (Difco). Inoculated flasks were kept still for $12 \mathrm{~h}$ at $33^{\circ} \mathrm{C}$ before being rotated in a rotary shaker (Type Sm 10, E. Bühler, Tübingen, Germany) at $120 \mathrm{rev} \cdot \mathrm{min}^{-1}$ for 4 to $5 \mathrm{~h}$.

Preparation of membrane fractions. Cytoplasmic and outer membranes were prepared by a slight modification of the method of Osborn et al. (1972). A portion $(420 \mathrm{ml})$ of a culture in the late exponential phase of 
growth $\left(A_{650}=0.8\right.$ to $1.5 ; 1 \mathrm{~cm}$ light path; Beckman DB spectrophotometer) was harvested by centrifuging at $4000 \mathrm{~g}$ for $5 \mathrm{~min}$ (all centrifugation was done at $4{ }^{\circ} \mathrm{C}$ ). The sediment was suspended in $100 \mathrm{ml}$ supernatant and centrifuged at $11000 \mathrm{~g}$ for $5 \mathrm{~min}$. The resulting pellet was immediately resuspended in $21 \mathrm{ml}$ ice-cold $0.75 \mathrm{M}$-sucrose, $10 \mathrm{~mm}$-Tris/ $\mathrm{HCl}, \mathrm{pH} 7.8$, and kept on ice for $8 \mathrm{~min}$. Then $1 \mathrm{ml}$ of a $7.5 \mathrm{mg} \mathrm{ml}^{-1}$ solution of lysozyme (Sigma) was added and the mixture was kept on ice for $2 \mathrm{~min}$. Next, $44 \mathrm{ml}$ cold $1.5 \mathrm{~mm}$-EDTA, $\mathrm{pH} 7.5$ was added from a burette at a constant rate with a spheroplast release time of 10 to $12 \mathrm{~min}$. Plasmolysis and spheroplast release were monitored by phase contrast microscopy.

The spheroplasts were osmotically lysed by dropwise addition of the suspension to $264 \mathrm{ml}$ cold distilled water followed by magnetic stirring for 5 to $10 \mathrm{~min}$ at $4{ }^{\circ} \mathrm{C}$. To remove remaining whole cells and spheroplasts, the lysate was centrifuged at $4000 \mathrm{~g}$ for $30 \mathrm{~min}$. The membranes were collected by centrifuging at $150000 \mathrm{~g}$ for $3 \mathrm{~h}$ (total membrane fraction, TM).

The sucrose gradient used in the next stage of the preparation was made $20 \mathrm{~h}$ before use to permit diffusion into a smooth gradient (Brakke, 1958). To obtain an inverted gradient of a sample by the method of Britten \& Roberts (1960), the total membrane fraction was divided into three portions containing increasing amounts of sucrose $(27,30$ and $33 \%)$ and decreasing amounts of sample $(50,30$ and $20 \%$ of the total protein added). These three membrane solutions were suspended by means of a 21 -gauge syringe and cannula and layered on top of a stepwise 35 to $60 \%$ sucrose-EDTA gradient, $0.5 \mathrm{mg}$ membrane protein being introduced into each tube. Centrifugation was at $170000 \mathrm{~g}$ for 12 to $16 \mathrm{~h}$. Fractions were collected from the top of the gradient in an apparatus similar to that described by Coombs (1975). To minimize cross-contamination, only the middle part of each band was used. The fractions were diluted in 1 mM-EDTA, $\mathrm{pH} \mathrm{7.5,} \mathrm{to} \mathrm{a} \mathrm{sucrose}$ concentration of less than $10 \%(\mathrm{w} / \mathrm{v})$, carefully suspended as before and centrifuged for $2 \mathrm{~h}$ at $150000 \mathrm{~g}$. The sediments obtained were used for electron microscope examinations and enzyme assays. Membrane fractions used for the determination of protein and fatty acid composition were washed by diluting 10- to 15 -fold in $1 \mathrm{~mm}$-EDTA, $\mathrm{pH} 7 \cdot 5$, and centrifuged for $4 \mathrm{~h}$ at $10000 \mathrm{~g}$. The washed fractions were suspended in 1 mM-EDTA, $\mathrm{pH} 7 \cdot 5$, and kept at $-20^{\circ} \mathrm{C}$.

Electron microscopy. Membrane fractions were negatively stained with $2 \%(\mathrm{w} / \mathrm{v})$ sodium silicotungstate, pH 7.4. For thin-sectioning, membranes were fixed in $2.5 \%$ (w/v) glutaraldehyde, $3 \mathrm{~mm}-\mathrm{CaCl}_{2}, 90 \mathrm{~mm}-$ cacodylate buffer, $\mathrm{pH} 7 \cdot 2$, for $1 \mathrm{~h}$ at room temperature (Thornley et al., 1973) and embedded in Spurr epoxy compound after dehydration in acetone. Thin sections were cut with glass knives on a Reichert OmU2 ultramicrotome (Reichert Optische Werke, Wien, Austria) and stained with lead citrate by the method of Mollenhauer (1974). Samples were examined in a JEOL JEM 100B transmission electron microscope ( $80 \mathrm{kV}$, objective aperture $35 \mu \mathrm{m}$, spot size $2 \mu \mathrm{m}$, short focal distance holder).

Gas-liquid chromatography. Membrane fractions were methanolysed and the resulting fatty acid methyl esters were analysed by the method of Jantzen et al. (1974) on a Hewlett-Packard gas chromatograph. The standards used were 1-hexadecanol, 1-octadecanol, and 2-hydroxydecanoic, 2-hydroxydodecanoic, 2hydroxytetradecanoic, 3-hydroxytetradecanoic, tetradecanoic and hexadecanoic acids (Applied Science Laboratories). The column (10\% SE-30 on Gas Chrom Q, 100 to 200 mesh, Applied Science Laboratories) was temperature programmed from 120 to $240{ }^{\circ} \mathrm{C}$ at $2{ }^{\circ} \mathrm{C} \mathrm{min}-1$.

Sodium dodecyl sulphate $(S D S)$-polyacrylamide gel electrophoresis. This was done with the Laemmli buffer system and an $18 \%(\mathrm{w} / \mathrm{v})$ polyacrylamide gel with $0.5 \%(\mathrm{w} / \mathrm{v}) N, N^{\prime}$-methylenebisacrylamide (BioRad) (Frøholm \& Sletten, 1977). For molecular weight determinations the following standard proteins were used: chicken egg albumin, chymotrypsinogen A, myoglobin (all from Koch-Light) and lysozyme (Sigma). Gels were stained with Coomassie brilliant blue R250 (BioRad) and destained by the method of Fairbanks et al. (1971). Photographs of gels were recorded with a Joyce Loebel Chromoscan MKII scanning densitometer (aperture $1750 \mu \mathrm{m}$ ).

For determination of the distribution of fimbrial protein in the two membrane fractions, each of the fimbrial protein bands and the bands of the other proteins in the membrane fraction were extracted from slices of stained gels by overnight immersion in $0.1 \%$ SDS; $A_{595}$ was measured in a Beckman DB spectrophotometer and the values were corrected for the absorbance of a corresponding blank gel.

Enzyme assays. Activities of succinate dehydrogenase (EC 1.3.99.1) and D-lactate dehydrogenase (EC 1.1.1.28) were assayed at $22^{\circ} \mathrm{C}$ as described by Osborn et al. (1972).

Protein determination. The method of Schaffner \& Weissman (1973) was used with bovine serum albumin (fraction V; Armour Pharmaceutical $\mathrm{Co}$.) as a standard. The protein content of the total membrane fraction was estimated by ultraviolet light spectroscopy at 260 and $280 \mathrm{~nm}$, using the formula of Warburg \& Christian (1942). 
Table 1. Relative fatty acid contents of the membrane fractions

The concentrations of each of five main fatty acids in the gas-liquid chromatography profile of the total membrane fraction (TM), cytoplasmic membrane fraction (L) and outer membrane fraction (H) are expressed as percentages of the total peak area.

\begin{tabular}{|c|c|c|c|c|}
\hline \multirow[b]{2}{*}{$\begin{array}{l}\text { Fatty acid } \\
\text { methyl ester }\end{array}$} & \multirow[b]{2}{*}{$\begin{array}{l}\text { Membrane } \\
\text { fraction }\end{array}$} & \multicolumn{3}{|c|}{ Concn of fatty acid $(\%)$} \\
\hline & & TM & $\mathrm{H}$ & $\mathrm{L}$ \\
\hline 3-Hydroxydod & & 5 & 15 & 1 \\
\hline Hexadecenoic & & 10 & 10 & 7 \\
\hline Hexadecanoic & & 20 & 18 & 16 \\
\hline Octadecenoic & & 32 & 34 & 47 \\
\hline Octadecanoic & & 10 & 12 & 7 \\
\hline Others & & 23 & 11 & 22 \\
\hline
\end{tabular}

Table 2. Enzyme distribution in membrane fractions

Enzyme activities were assayed in the total membrane fraction (TM), cytoplasmic membrane fraction $(\mathrm{L})$ and outer membrane fraction $(\mathrm{H})$. The enzyme activities of the fractions corrected for fimbrial protein content are shown in parentheses.

\begin{tabular}{|c|c|c|c|}
\hline \multirow{2}{*}{$\begin{array}{c}\text { Membrane } \\
\text { Enzyme } \\
\text { fraction } \ldots\end{array}$} & \multicolumn{3}{|c|}{$\begin{array}{c}\text { Specific activity } \\
{\left[\mu \mathrm{mol} \min ^{-1}(\mathrm{mg} \text { protein })^{-1}\right]}\end{array}$} \\
\hline & TM & $\mathrm{L}$ & $\mathrm{H}$ \\
\hline Succinate dehydrogenase & $\begin{array}{c}0 \cdot 25 \\
(0 \cdot 31)\end{array}$ & $\begin{array}{c}0 \cdot 59 \\
(4 \cdot 00)\end{array}$ & ND \\
\hline D-Lactate dehydrogenase & $\begin{array}{l}1.38 \\
(1.69)\end{array}$ & $\begin{array}{c}2 \cdot 94 \\
(20 \cdot 00)\end{array}$ & $\begin{array}{c}0.46 \\
(0 \cdot 50)\end{array}$ \\
\hline
\end{tabular}

ND, Not detected.

RESULTS

\section{Preparation of membrane fractions}

Sucrose-EDTA gradient centrifugation of the total membrane fraction (TM) gave two major well-separated bands; the upper band, isolated as fraction $\mathrm{L}$, had a density of $1 \cdot 17$ to $1.18 \mathrm{~g} \mathrm{~cm}^{-3}$ and the lower band, isolated as fraction $\mathrm{H}$, had a density of 1.24 to $1.27 \mathrm{~g} \mathrm{~cm}^{-3}$. Low yields were obtained when the release of spheroplasts was incomplete. The degree of separation was critically dependent on the efficiency of plasmolysis. The recovery of protein in TM was 13 to $15 \%$, and the distribution of protein between $\mathrm{L}$ and $\mathrm{H}$ was 10 to $14 \%$ and 18 to $22 \%$ of that in TM, respectively.

Fimbrial protein, revealed by extraction of SDS-polyacrylamide gel strips, constituted $85 \%$ of the total protein of fraction $\mathrm{L}$ and $1 \%$ of that of fraction $\mathrm{H}$.

\section{Chemical characterization of the membrane fractions}

The fatty acid composition and distribution of specific enzymes of fractions $\mathrm{L}$ and $\mathrm{H}$ are shown in Tables 1 and 2. The specific lipopolysaccharide (LPS) marker, 3-hydroxydodecanoic acid (K. Bryn, unpublished results), was found almost exclusively in the $\mathrm{H}$ fraction (Table 1 ).

Succinate and D-lactate dehydrogenase activities were more than twofold higher in $\mathrm{L}$ than in TM and the D-lactate dehydrogenase activity of $L$ was about 6.5 times that of $H$. In the latter fraction no succinate dehydrogenase activity could be detected, whereas Dlactate dehydrogenase activity was just detectable (Table 2). The higher activities of succinate and D-lactate dehydrogenases obtained when corrections were made for the fimbrial protein content of the fractions are also included in Table 2 . These results indicated that the $\mathrm{L}$ fraction contained cytoplasmic membrane material. The absence or low activities of the 

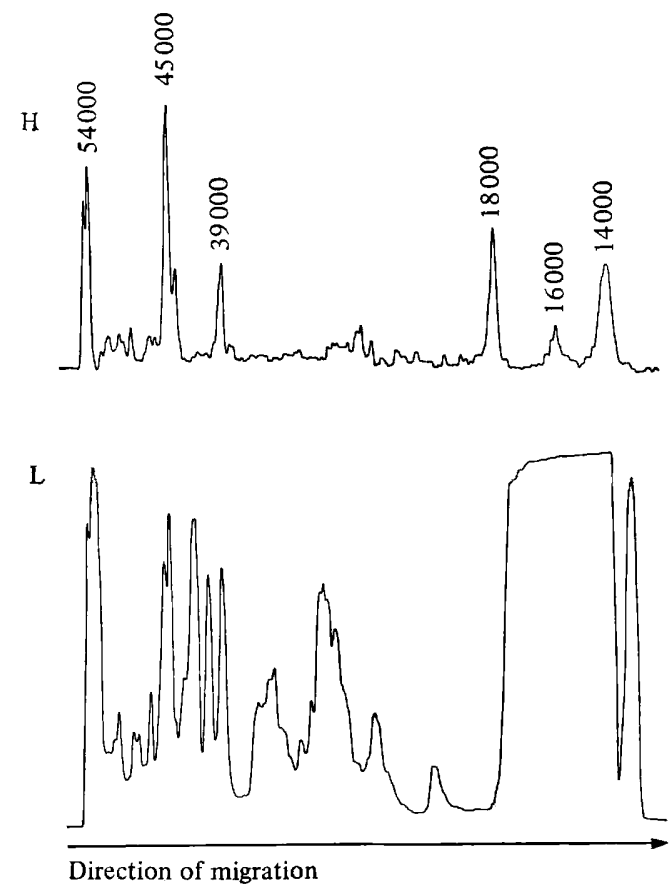

Fig. 1. Densitometer tracings of protein profiles on $18 \%(w / v)$ SDS-polyacrylamide gels: L, cytoplasmic membrane fraction; $\mathrm{H}$, outer membrane fraction. The major protein bands of the outer membrane fraction are indicated by their apparent molecular weights.

enzymes and the high LPS content indicated that the $\mathrm{H}$ fraction was outer membrane material.

\section{SDS-polyacrylamide gel electrophoresis}

The protein composition of the membrane fractions was studied by SDS-polyacrylamide gel electrophoresis (Fig. 1). The cytoplasmic membrane fraction contained a large number of protein bands, in particular several which were slow moving and so of high molecular weight. The outer membrane fraction, on the other hand, contained six major bands which, by comparison with standards, were calculated to have molecular weights of 54000, 45000, $39000,18000,16000$ and 14000 , with the 45000 polypeptide predominating (Fig. 1). The 18000 molecular weight band, presumably representing fimbrial protein, dominated the cytoplasmic membrane fraction but was only one of several major proteins of the outer membrane fraction. The 14000 molecular weight material represented the lysozyme used in the preparation of spheroplasts.

\section{Electron microscopy}

Negatively stained outer membrane fraction (Fig. $2 b$ ) revealed membrane fragments of various sizes and only a few fimbriae (arrowed). Thin sections of the same material (Fig. $3 c, d$ ) indicated that the peptidoglycan structure was only partly degraded (double arrow). The membrane fragments were typically $\mathrm{C}$-shaped or spherical as has been observed by others (Miura \& Mizushima, 1968; Schnaitman, 1970).

Negatively stained preparations showed that the $L$ fraction contained vesicle-like structures together with flat or folded sheets of membranes, all with a granular appearance (Fig. $2 a$ ). There were many fimbriae in this fraction (arrowed) compared with the outer membrane fraction. In thin section (Fig. $3 a, b$ ) the $\mathrm{L}$ fraction contained straight membranes and open as well as closed membranous vesicles (approximately 0.03 to $0.3 \mu \mathrm{m} \mathrm{diam}$.). All displayed a single unit membrane. 

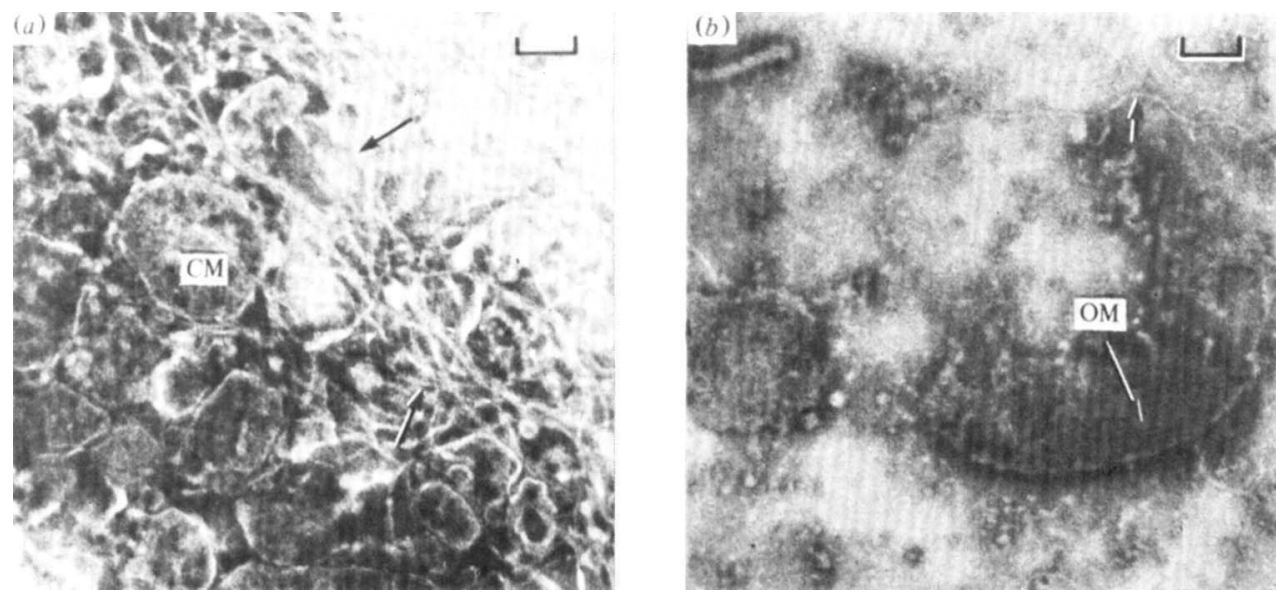

Fig. 2. Electron micrographs of negatively stained membrane fractions from Moraxella nonliquefaciens strain 7784 SC-c: $(a)$ cytoplasmic membrane fraction $(\mathrm{L}) ;(b)$ outer membrane fraction (H). OM represents a $\mathrm{C}$-shaped outer membrane fragment; $\mathrm{CM}$, a cytoplasmic membrane vesicle. Unlabelled arrows point to fimbriae. Bar markers represent $0 \cdot 1 \mu \mathrm{m}$.
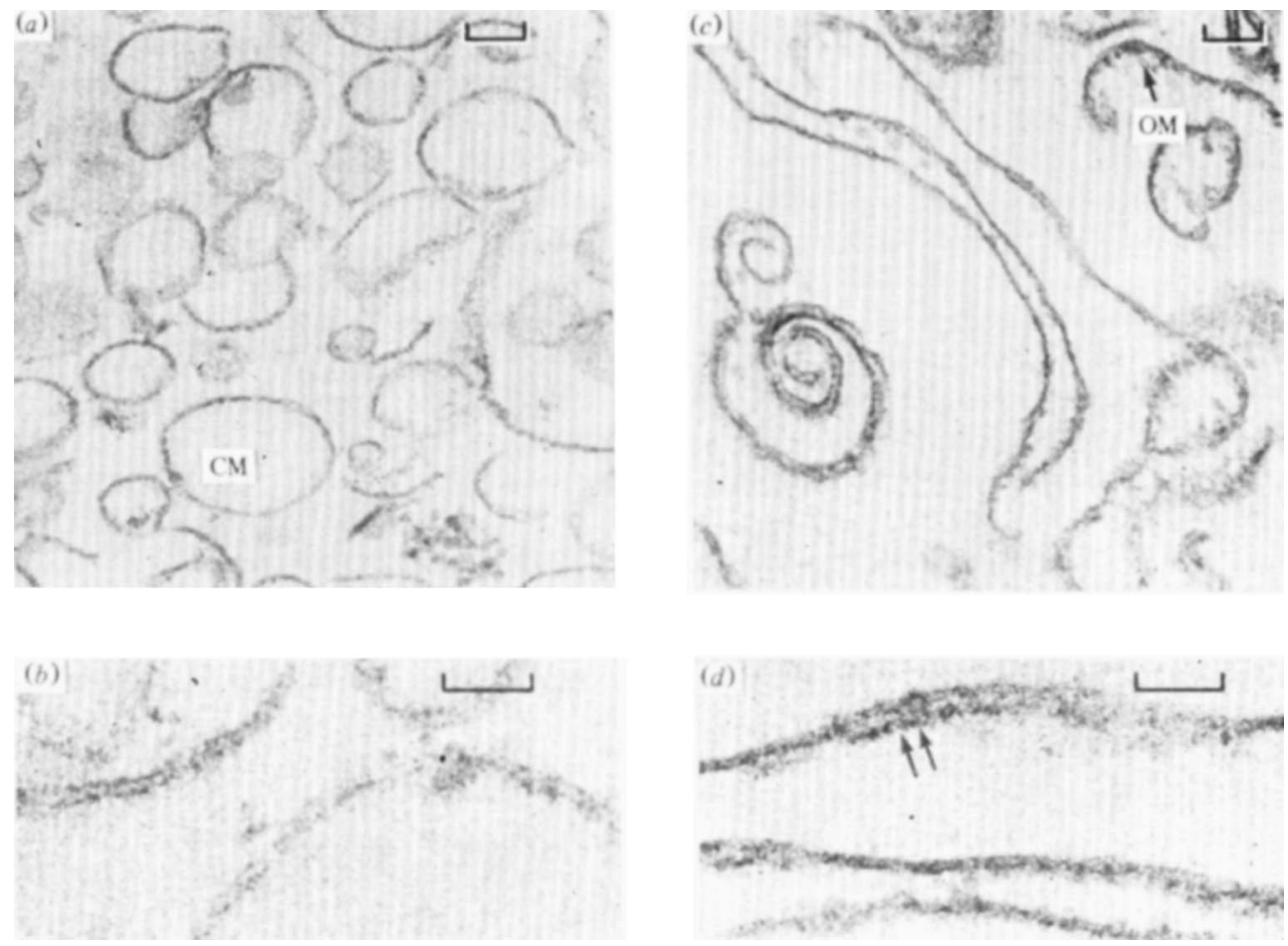

Fig. 3. Electron micrographs of thin-sectioned membrane material from Moraxella nonliquefaciens strain 7784 SC-c: $(a)$ cytoplasmic membrane fraction $(\mathrm{L}) ;(b)$ detail of the cytoplasmic membrane fraction; $(c)$ outer membrane fraction $(\mathrm{H}) ;(d)$ detail of the outer membrane fraction. Double arrows indicate partly degraded peptidoglycan; OM, a typical $\mathrm{C}$-shaped outer membrane fragment; $\mathrm{CM}$, a cytoplasmic membrane vesicle. Bar markers represent $0 \cdot 1 \mu \mathrm{m}$ in $(a, c)$ and $0.05 \mu \mathrm{m}$ in $(b, d)$. 


\section{DISCUSSION}

The method of Osborn et al. (1972), slightly modified, was used to isolate membrane fractions of $M$. nonliquefaciens. The yield of total membrane protein per $\mathrm{ml}$ cell culture was about the same as that reported by Osborn \& Munson (1974) for Salmonella typhimurium.

Separation of the membrane material by gradient centrifugation provided two distinct bands, and distribution of the $\mathrm{L}$ fraction material into two bands did not occur. The gradient was designed to give good separation of the $\mathrm{L}$ and $\mathrm{H}$ regions. The yield of membrane protein in the two fractions was about $50 \%$ of that reported by Osborn et al. (1972). The distribution was thus somewhat simpler because the $M$ band, representing unseparated material, was never observed. The $\mathrm{L}$ fraction contained a high proportion $(85 \%)$ of fimbrial protein, yet determination of enzyme activity and electron microscopic examination showed that this fraction contained the cytoplasmic membrane material. The low membrane protein content of the fraction may indicate that there is a selective loss of cytoplasmic membrane material during the isolation procedure. Electron microscopic examination of $M$. nonliquefaciens strain 7784 SC-c (Frøholm, 1978) has shown that it is highly fimbriated. We therefore assume that the fimbriae entrapped cytoplasmic membrane fragments and made them easy to sediment during differential centrifugation.

The protein composition of the fractions, as shown by SDS-polyacrylamide gel electrophoresis, indicated that there was little cross-contamination.

The outer membrane material was characterized by its relatively high content $(15 \%)$ of 3-hydroxydodecanoic acid. Since this hydroxy acid can be considered as a specific LPS marker, the LPS content of the outer membrane fraction was 15 times higher than that of the cytoplasmic membrane. The major fatty acid in both the outer and the cytoplasmic membrane fractions was octadecenoic acid. The unsaturated fatty acids, hexadecenoic and octadecenoic acids, seemed to contribute more to the total fatty acid content of the cytoplasmic membrane fraction $(54 \%)$ than to that of the outer membrane fraction $(44 \%)$. Other fatty acids not included in Table 1 were mainly wax constituents (unpublished results).

D-Lactate and succinate dehydrogenase were detected mainly in the $\mathrm{L}$ fraction. These results are in accordance with those of Osborn et al. (1972) for S. typhimurium and may show a possible $15 \%$ contamination of the $\mathrm{H}$ fraction by $\mathrm{L}$ fraction material.

Micrographs of thin sections of the outer membrane fraction show that the peptidoglycan layer was only partly degraded. This may have been because the relatively complex surface layers of $M$. nonliquefaciens hampered degradation of the peptidoglycan.

Electron microscopy also revealed that most of the fimbriae were located in the cytoplasmic membrane fraction. The content of fimbrial protein in the outer membrane fraction revealed by SDS-polyacrylamide gel electrophoresis was $1 \%$ of that of the cytoplasmic membrane fraction. If we assume that the fimbriae were attached to the cytoplasmic membrane, this confirms the low degree of contamination, but does not rule out the presence of a pool of fimbrial protein in the outer membrane as indicated by Beard \& Connolly (1975) in Escherichia coli. According to our results, however, this pool should be fairly small, assuming that about half of the fimbrial protein found in the outer membrane fraction represents contamination from the cytoplasmic membrane.

We thank T. Lea and B. Tveitnes for the preparation of thin sections for electron microscopy. 


\section{REFERENCES}

Beard, J. P. \& Connolly, J. C. (1975). Detection of a protein similar to the sex pilus subunit, in the outer membrane of Escherichia coli cells carrying a derepressed F-like R factor. Journal of Bacterio$\log y$ 122, 59-65.

BRAKKE, M. K. (1958). Estimation of sedimentation constants of viruses by density-gradient centrifugation. Virology 6, 96-114.

Britten, R. J. \& Roberts, R. B. (1960). High resolution density gradient sedimentation analysis. Science 131, 32-33.

Coombs, D. H. (1975). Density gradient fractionation by piston displacement. Analytical Biochemistry 68, 95-101.

Fairbanks, G., Steck, T. L. \& Wallach, D. F. H. (1971). Electrophoretic analysis of the major polypeptides of the human erythrocyte membrane. Biochemistry 10, 2606-2617.

FrøHolm, L. O. (1978). Antigenic characteristics of Moraxella nonliquefaciens fimbriae in double immunodiffusion. Acta pathologica et microbiologica scandinavica B86, 169-178.

FrøноLм, L. O. \& Bøvre, K. (1978). Density gradient centrifugation in Urografin of Moraxella and Kingella cells and appendages. Acta pathologica et microbiologica scandinavica B86, 77-86.

Frøholm, L. O. \& Sletten, K. (1977). Purification and $\mathrm{N}$-terminal sequence of a fimbrial protein from Moraxella nonliquefaciens. FEBS Letters 73, 29-32.

Jantzen, E., Bryn, K. \& Bøvre, K. (1974). Gas chromatography of bacterial whole cell methanolysates. IV. A procedure for fractionation and identification of fatty acids and monosaccharides of cellular structures. Acta pathologica et microbiologica scandinavica B82, 753-766.
Mollenhauer, H. H. (1974). Poststaining sections for electron microscopy. Stain Technology 49, 305-307.

Miura, T. \& Mizushima, S. (1968). Separation by density gradient centrifugation of two types of membranes from spheroplast membrane of Escherichia coli K12. Biochimica et biophysica acta 150, 159-161.

Osborn, M. J. \& Munson, R. (1974). Separation of the inner (cytoplasmic) and outer membranes of Gram-negative bacteria. Methods in Enzymology 31, 642-653.

Osborn, M. J., Gander, J. E., Parisi, E. \& Carson, J. (1972). Mechanism of assembly of the outer membrane of Salmonella typhimurium. Isolation and characterization of cytoplasmic and outer membrane. Journal of Biological Chemistry 247, 3962-3972.

SchafFNeR, W. \& WeIssman, C. (1973). A rapid, sensitive, and specific method for the determination of protein in dilute solution. Analytical Biochemistry 56, 502-514.

Schnattman, C. A. (1970). Protein composition of the cell wall and cytoplasmic membrane of Escherichia coli. Journal of Bacteriology 104, 890-901.

Thornley, M. J., Glauert, A. M. \& Sleytr, U. B. (1973). Isolation of outer membranes with an ordered array of surface subunits from Acinetobacter. Journal of Bacteriology 114, 1274-1308.

Warburg, O. \& Christian, W. (1942). Isolierung und Kristallisation des Gärungsferments Enolase. Biochemische Zeitschrift 310, 384-421. 